\title{
Evaluation of the repellent effect of Dioscorea sansibarensis PAX (Dioscoreaceae) leaf essential oil against Bruchus chinensis LINNAEUS, 1758 (Coleoptera: Bruchidae)
}

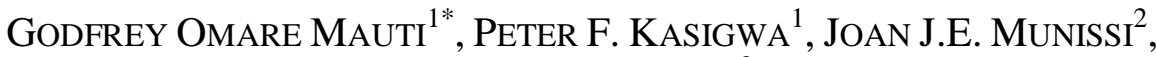 JuSTUS M. ONGUSO ${ }^{3}$}

${ }^{1}$ Department of Zoology and Wildlife Conservation, College of Natural and Applied Sciences University of Dar es Salaam, Dar es Salaam, Tanzania

${ }^{2}$ Chemistry Department, College of Natural and Applied Sciences, University of Dar es Salaam, Dar es Salaam, Tanzania

${ }^{3}$ Institute of Biotechnology Research, Jomo Kenyatta University of Agriculture and Technology, Nairobi, Kenya

\begin{abstract}
Laboratory experiments were conducted to determine the repellent activities of the ornamental plant Dioscorea sansibarensis leaf essential oil against the Bruchus chinensis bean weevil in the protection of stored legumes. The leaves exhibited potential repellency in a Y-tube olfactometer. The tabulated data show that $10 \mu \mathrm{L}$ of leaf oil exhibited a repellency of $41.33 \%$, with a grouped median of $53.33 \%$, which was better than $10 \mu \mathrm{L}$ of Actellic $50 \mathrm{EC}$, which had a repellency of $36.00 \%$ and a grouped median of $40 \%$. Statistically, there was no significant difference in the percentage repellency obtained from the leaf oil and Actellic $50 \mathrm{EC}$ at different concentrations $\left(10,20,30\right.$ and $\left.40 \mu \mathrm{L} / \mathrm{mL}, X^{2}(7, N=200)=114.93, P<0.05\right)$. The GC-MS analysis identified 16 compounds in the leaf oil. The main compounds and their percentage composition were phytol (19.46\%), 1-epi- $\alpha$-gurjunene $(11.71 \%)$, palmitic acid $(10.48 \%)$, ethyl palmitate (8.87\%), methyl palmitate (7.72\%), isophytol (5.99\%), 2-heptadecanone (4.59\%) and $\alpha$-selinene $(4.5 \%)$. The repellency caused by the by leaf oil may have been due to the presence of $\alpha$-selinene, also known as naphthalene, 1,2,3,5,6,7,8,8a-octahydro-1,8a-dimethyl-7-(1-methylethenyl)-, [1S-

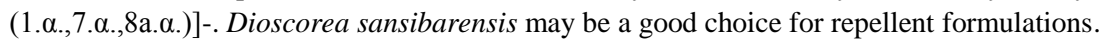

KEY WORDS: Bruchus chinensis, Dioscorea sansibarensis leaves, essential oil, Y-tube olfactometer, repellency.

* Corresponding author: godiomari@yahoo.com 


\section{INTRODUCTION}

Bruchus chinensis LinNAEUS, 1758 (Coleoptera: Bruchidae) is also known as Callosobruchus chinensis (LINNAEUS, 1758) and the Chinese bruchid (MUKERJ \& BHUYA 1937). Bruchus chinensis breeds in every continent except Antarctica and is common in the tropical and subtropical regions of Asia, Africa, and Central and South America (KUMAR \& KUMAR 2018). This pest has a close association mainly with leguminous plants, where it damages seeds (beans), both in the field and in stores. The beetle lays its eggs on the seed surface, from where the newly-hatched larvae bore into the seed. Pupation takes place inside the bean seed, from which the adult emerges (HoNG et al. 2017).

B. chinensis management is usually based on a range of synthetic pesticides in the form of gaseous fumigants, solutions and residual insecticides (TRIPATHI 2018). Actellic 50 EC mixed with water is sprayed onto seeds and/or storage sacks, or fumigated on the inside walls of silos and granaries to prevent attack by B. chinensis beetles (NGOWI et al. 2007). Current research has shown that the Actellic 50 EC residues which remain on the seeds may have adverse effects on humans and the environment in the form of biomagnification and toxicity to non-target organisms. Persistent usage of Actellic $50 \mathrm{EC}$ has also been found to increase resistance to the target insects (MASSALATCHI et al. 2017). Finding and developing alternative insecticides from botanicals as a strategy for sustainable insect pest management in agriculture is crucial. They are convenient to use, since they are biodegradable, environmentally-friendly and safe. Hence, they are potentially suitable for use as pure compounds or in an integrated form, as some are specific while others can have multiple target sites (KARANI et al. 2017, CAMPOS et al. 2018).

Plants contain secondary metabolites, which on the one hand protect them from being eaten by herbivores and from being infected by microbial pathogens, and on the other serve as attractants for pollinators and seed-dispersing animals. These characteristics have imparted different properties to plants, as a result of which they have medicinal, antimicrobial and insectivorous uses, among others (SABIHA et al. 2017). Natural insecticides of plant origin have been investigated in the form of powders and slurries, ashes, aqueous/solvent extracts and oils. In some cases, plant extracts exhibit repellent activity when they are mixed with seeds; in others, they attract and kill storage pests when these ingest them (UPADHYAY \& AHMAD 2011, CAMPOLO et al. 2018).

Although there are numerous reports on the repellent activities of plant oils on bruchids, fewer data have been published regarding their repellency against $B$. chinensis. Plant essential oil from sweet flag (Acorus calamus L.) has been found to have repellent chemosterilant properties against Collasobruchus maculatus (FABRICIUS, 1775) (JAYAKUMAR et al. 2017). Oils from cinnamon (Cinnamomum zeylanicum J.PRESL), clove (Syzygium aromaticum (L.) MERRILL \& PERRY), rosemary (Rosmarinus officinalis L.), 
bergamot (Citrus bergamia RISSO) and Japanese mint (Mentha arvensis L.) have repellent activities against Bruchus dentipes (BAUDI, 1886) (TRIVEDI et al. 2017). CHILUWAL et al. (2017) reported repellency against B. chinensis by oils from Star anise (Illicium verum HоOK. F.), Linaloe berry (Bursera delpechiana PoIss.), Croton (Croton anisatum BAILL.), Chinese cassia (Cinnamomum cassia (L.) J.PRESL) and Brazilian rosewood (Aniba rosaeodora DUCKE).

The Dioscorea sansibarensis PAX liana, native to Tanzania, is one of the largest and most widely distributed species of the genus Dioscorea L. in the coastal zones. The climber produces both bulbils and underground tubers, which several researchers have characterized as toxic. Despite its vegetative parts being evergreen and the leaves broadly and openly distributed, they are undamaged by chewing insects and destructive herbivores avoid feeding on them. The leaves of the plant have a characteristic scent when crushed into a paste. Traditionally $D$. sansibarensis has been used for medicinal purposes and of late it has gained pharmaceutical interest (BURKILL 1985, PRICE et al. 2016, KUMAR et al. 2017). The present study focuses on assessing the repellent potency of the essential oil retrieved from the leaves of D. sansibarensis against the notorious pest Bruchus chinensis and to analyse the compounds present using GC-MS.

\section{MATERIALS AND METHODS}

\section{Plant material}

The leaves of $D$. sansibarensis were collected in the Zoological-Botanical forests of the University of Dar es Salaam ( $6^{\circ} 45^{\prime} 0^{\prime \prime} \mathrm{S}, 39^{\circ} 15^{\prime} 0^{\prime \prime}$ E, altitude $80 \mathrm{~m}$ above sea level) and taken to the Entomology Laboratory of the Department of Zoology and Wildlife Conservation at the University of Dar es Salaam, Tanzania. Morphological identification was performed at the herbarium of the Botany Department of the same institution, where the voucher with the reference number FMM 3910a is deposited.

\section{Extraction of $D$. sansibarensis leaf essential oil}

Freshly collected $D$. sansibarensis leaves were thoroughly washed with tap water, rinsed with distilled water and left to dry in the shade in a well-ventilated area for 5 days at room temperature. After drying, $250 \mathrm{~g}$ of leaves were macerated and homogenized using an electric grinder in the laboratory. The oil was extracted from the homogenized leaves by hydro-distillation using a Clevenger type apparatus for 4 hours to yield a water and oil mixture. The oil was separated from water by solvent-solvent extraction using diethyl ether in a separating funnel, and concentrated under vacuum in a rotary evaporator at 
a temperature of $40{ }^{\circ} \mathrm{C}$. The oil was stored in a refrigerator at $4{ }^{\circ} \mathrm{C}$ and subsequent used in the bioassays.

\section{Analysis of compounds using gas chromatography coupled to mass spectrometry}

The identity of the essential oil constituents was established by GC-MS performed on a Hewlett-Packard HP 5973 mass spectrometer interfaced with an HP 6890 gas chromatograph. The mass selective detector was operated in electron impact mode with an ionization energy of $70 \mathrm{eV}$ and a mass range from $\mathrm{m} / \mathrm{z}$ 40-380. An HP-5 column (30 m long and $0.25 \mathrm{~mm}$ internal diameter with a film thickness of $0.25 \mu \mathrm{m}$ ) was initially kept at a temperature of $60{ }^{\circ} \mathrm{C}$, then gradually heated to $250{ }^{\circ} \mathrm{C}$ at $5{ }^{\circ} \mathrm{C} / \mathrm{min}$ intervals. The carrier gas was helium (99.9\%). In some cases where the separation of peaks was inadequate, the temperature and programme rate were adjusted. Each sample was dissolved in hexane to give a $1 \% \mathrm{w} / \mathrm{v}$ solution; $0.2 \mu \mathrm{L}$ of the oil sample was injected into the GC-MS equipment at a temperature of $250{ }^{\circ} \mathrm{C}$, from which the gas chromatograms and mass spectra were obtained.

Mass spectral deconvolution and automated calculation of the retention index was performed by the automated mass spectral deconvolution and National Institute of Standards and Technology (NIST). Standard solutions of linear alkanes $\left(\mathrm{C}_{7}-\mathrm{C}_{30}\right.$, SigmaAldrich 49451-U) were used for Kovats RI calibration in the GC-MS system. Data deconvolution was performed with the following specifications: component width $=12$; adjacent peak subtraction $=2$; resolution $=$ low; sensitivity $=$ very low; shape requirements $=$ medium. Compounds were identified from the deconvoluted mass spectra by comparison, matching their spectra to those recorded in the Wiley 275 and NIST Mass Spectral Library with reference to the associated database and literature.

\section{Preparation of working solutions}

Working solutions with different concentrations were prepared by diluting 10, 20, 30 and $40 \mu \mathrm{L}$ of oil in $1 \mathrm{~mL}$ of acetone, while water was used as the diluting solvent for the doses serving as the positive control. These doses represented the respective concentrations of $0.036,0.072,0.108$ and $0.144 \mathrm{mg} / \mathrm{mL}$ for leaf oil and $0.01,0.02,0.03$ and $0.04 \mathrm{mg} / \mathrm{mL}$ for the positive control (Actellic $50 \mathrm{EC}$ ). The commercial synthetic pesticide Actellic 50 EC $(500 \mathrm{~g} / \mathrm{L} \mathrm{AI}, 100 \mathrm{~g} / 90 \mathrm{~kg}$ Syngenta, Switzerland) was purchased from agricultural input suppliers in Dar es Salaam for use as the positive control.

\section{Culturing of Bruchus chinensis}

Healthy common bean (Phaseolus vulgaris L.) seeds were purchased directly from the farm after harvest. The seeds were thoroughly cleaned, sun-dried and stored with $10 \pm 2 \%$ moisture content. $1 \mathrm{~kg}$ of undamaged, healthy $P$. vulgaris beans were dried under direct 
sunlight for 7 days, disinfested in an oven at $60{ }^{\circ} \mathrm{C}$ for 1 hour and placed in glass jars (27 $\mathrm{cm}$ height $\times 16 \mathrm{~cm}$ diameter). Approximately 400 adults of Bruchus chinensis beetles were released into the jar, the mouth of which was then covered with muslin cloth and secured with a rubber band. These jars were then incubated in darkness at $28 \pm 2{ }^{\circ} \mathrm{C}$ and $65 \pm 5 \%$ relative humidity $(\mathrm{RH})$ for mating and oviposition for 7 days. Thereafter, the beetles were separated from the seeds by sieving and returned to their container for continual incubation. Incubation was continuous in order to maintain reproduction. Afterwards the emerged insects were used in the bioassays.

\section{Repellency assay}

The repellent activity of the essential oil against $B$. chinensis was assessed using a $Y$ shaped olfactometer. The Y-tube was placed in the centre of a $23 \times 16 \times 11 \mathrm{~cm}$ black box, lined with black paper to prevent visual stimuli produced by the halogen lamp during illumination. The Y-tube olfactometer consisted of a "Y" shaped glass tube with three compartments (arms), each $10 \mathrm{~mm}$ in diameter and $10 \mathrm{~cm}$ in length. These compartments were the treatment arm, the control arm and the arm for introducing the beetle. The end of each arm was fitted with glass stoppers of appropriate sizes $(3 \mathrm{~cm}$ in diameter). The stoppers had two narrow grooves allowing airflow into the olfactometer during the bioassays.

Filter paper discs (Whatman No. 1, of diameter $1 \mathrm{~cm}$ and weighing $140 \mathrm{mg}$ ) were dipped into the various dilutions of leaf oil and the positive controls (10, 20, 30 and 40 $\mu \mathrm{L} / \mathrm{mL}$ ) and allowed to dry in air. Acetone was used to sterilize the filter paper disc that was used as the negative control disc. The discs were inserted into their compartments, prior to the introduction of the weevils, and air-suction was applied at the Y-junction by means of an aspirator pump. This ensured that the olfactometer did not become saturated with the vapour from the oil, which was confined to the treatment arm of the olfactometer. The insects were induced by light and allowed to walk and decide which arm to move to at the "Y" shape bifurcation. All the air from the olfactometer to the aspirator pump was carried out away in a Tygon tube from the pump outlet.

For each assay, 10 pairs of weevils were selected and introduced into the olfactometer at once. Advantage was taken of the fact that the weevils are negatively phototactic by illuminating the introduction compartment of the weevils into the olfactometer with light from a $60 \mathrm{~W}$ bulb placed $15 \mathrm{~cm}$ away and screening the rest of the olfactometer in a carton. An average of $80-85 \%$ of the weevils was thus induced to migrate from the introduction arm to either the control or treatment arm during the period of the bioassay. The assay was left to run for one hour and then the number of weevils in the control arm (NC) and the treatment arm (NT) were counted. Percentage repellency (PR) values were computed using the formula: 


$$
\% \mathrm{PR}=\{(\mathrm{NC}-\mathrm{NT}) /(\mathrm{NC}+\mathrm{NT})\} \times 100
$$

where: \%PR: Percentage repellency

$\mathrm{N}_{\mathrm{C}}$ : Number of weevils in the control arm

$\mathrm{N}_{\mathrm{T}}$ : Number of weevils in the treatment arm

\section{Statistical analyses}

All weevil repellency data were recorded, converted to percentages and the means compared by Duncan's New Multiple Range Test (DMRT) using the statistical program Minitab 2017 (version 18). One-way non-parametric ANOVA (Kruskal-Wallis H test) was used to determine the differences in the effectiveness of Dioscorea sansibarensis leaf oil and the positive control (Actellic 50 EC) at different concentrations (10, 20, 30 and 40 $\mu \mathrm{L} / \mathrm{mL}$ ) using SPSS software (version 20), which included a normality test as well as homogeneity distribution and post-hoc analysis using Tukey's HSD test at $P \leq 0.05$. In this model, the treatment doses and exposure duration were the independent variables, and the percentage repellency was the dependent variable.

\section{RESULTS}

\section{Constituents of $D$. sansibarensis leaf essential oil}

D. sansibarensis leaves yielded $0.26 \pm 0.02 \%$ (w/w) oil, with a density of $0.74 \pm 0.08$ $\mathrm{g} / \mathrm{mL}$. GC-MS analysis revealed a total of 16 different compounds, eluted by GC-MS analyser over a period of 30 minutes. The main components and their percentage compositions were phytol (19.46\%), 1-epi- $\alpha$-gurjunene (11.71\%), palmitic acid (10.48\%), ethyl palmitate $(8.87 \%)$, methyl palmitate $(7.72 \%)$, isophytol (5.99\%), 2-heptadecanone (4.59\%) and $\alpha$-selinene (4.5\%) (Table 1$)$.

\section{Repellency effect of $\boldsymbol{D}$. sansibarensis leaf oil against Bruchus chinensis}

B. chinensis beetles were subjected to an oil vapour test for 1 hour in the Y-tube olfactometer. The tabulated data show that Dioscorea sansibarensis leaf essential oil displayed repellent activity against Bruchus chinensis. $10 \mu \mathrm{L}$ of leaf oil exhibited $41.30 \%$ repellency, $10 \mu \mathrm{L}$ of the positive control $36 \%$ (Table 2). The sample size $(\mathrm{n}=200)$ was analysed for normality: the Shapiro-Wilk test showed a non-normal distribution of repellency except in the data relating to the treatments with $20 \mu \mathrm{L}$ of leaf oil, and 10 and 20 $\mu \mathrm{L}$ of Actellic $50 \mathrm{EC}$. The non-parametric Levene test showed that the data was 
Table 1. Kovats retention index, retention time and percentage chemical composition of the compounds identified in the GC-MS analysis of the oil extracted from Dioscorea sansibarensis leaves.

\begin{tabular}{cccrr}
\hline No. & $\mathbf{R T}^{\mathbf{a}}$ & Constituents & $\mathbf{R I}^{\mathbf{b}}$ & $\boldsymbol{\%}^{\mathbf{c}}$ \\
\hline 1 & 21.49 & $\alpha$-Copaene & 1375 & 2.95 \\
2 & 22.12 & 1-Epi- $\alpha$-gurjunene & 1409 & 11.71 \\
3 & 24.07 & $\gamma^{-}$-Muurolene & 1477 & 2.69 \\
4 & 24.31 & Trans- $\beta$-ionone & 1489 & 2.44 \\
5 & 24.48 & $\alpha$-Selinene & 1493 & 4.50 \\
6 & 26.78 & 1-Heptadecene & 1692 & 2.05 \\
7 & 29.18 & 2-Heptadecanone & 1886 & 4.59 \\
8 & 31.16 & 1-Nonadecene & 1894 & 2.84 \\
9 & 33.87 & Methyl palmitate & 1927 & 7.72 \\
10 & 34.28 & Isophytol & 1947 & 5.99 \\
11 & 34.77 & Palmitic acid & 1970 & 10.48 \\
12 & 35.18 & Ethyl palmitate & 1993 & 8.87 \\
13 & 37.37 & Phytol & 2113 & 19.46 \\
14 & 38.76 & Behenic alcohol & 2468 & 2.39 \\
15 & 43.73 & Hexacosane & 2600 & 1.41 \\
16 & 46.69 & Pentatriacontane & 3500 & 1.66 \\
\hline
\end{tabular}

${ }^{a}$ Retention time (minute); ${ }^{\mathrm{b}}$ the Kovats Retention Indices were calculated from our analysis with respect to a series of $\mathrm{n}$-alkenes; ${ }^{\mathrm{c}}$ Percentage composition of a compound.

Table 2. Repellency ( $\% \pm$ S.E.) by $D$. sansibarensis leaf oil against Bruchus chinensis using a Y-tube olfactometer.

\begin{tabular}{lcccc}
\hline \multirow{2}{*}{ Treatement } & \multicolumn{4}{c}{ Concentration $[\boldsymbol{\mu L} / \mathbf{d i s c}]$} \\
\cline { 2 - 5 } & $\mathbf{1 0}$ & $\mathbf{2 0}$ & $\mathbf{3 0}$ & $\mathbf{4 0}$ \\
\hline Leaf oil & $41.3 \pm 15.1^{\mathrm{a}}$ & $58.67 \pm 7.72^{\mathrm{b}}$ & $68 \pm 9.29^{\mathrm{b}, \mathrm{c}}$ & $85.33 \pm 7.12^{\mathrm{d}, \mathrm{e}}$ \\
Actellic 50 EC & $36 \pm 10.5^{\mathrm{a}}$ & $64 \pm 9.09^{\mathrm{b}, \mathrm{c}}$ & $74.67 \pm 6.11^{\mathrm{c}, \mathrm{d}}$ & $93.33 \pm 2.11^{\mathrm{e}}$ \\
\hline
\end{tabular}

Treatments with the same letters in the table are not statistically significantly different from each other. $(\mathrm{N}=200),(P<0.05)$ using Tukey's HSD test.

heterogeneous at $\mathrm{L}(7,199.27), P<0.05$. The Kruskal-Wallis $\mathrm{H}$ test indicated that there was no statistically significant difference in the percentage repellency obtained from the leaf oil and the Actellic $50 \mathrm{EC}$ at different concentrations $\left(10,20,30\right.$ and $40 \mu \mathrm{L} / \mathrm{mL}, X^{2}(7, N=200)$ $=114.93, P<0.05$ ). 
Statistically, $10 \mu \mathrm{L}$ of leaf oil had a grouped median of $53.3 \%$, whereas $10 \mu \mathrm{L}$ of Actellic $50 \mathrm{EC}$ had $40 \%$. Post-hoc analysis showed homogeneity in $10 \mu \mathrm{L}$ of leaf oil and 10 $\mu \mathrm{L}$ of Actellic $50 \mathrm{EC}$, which achieved respective repellencies of $41.33 \%$ and $36.00 \%$. Treatments using $20 \mu \mathrm{L}$ of Actellic (64\%), $30 \mu \mathrm{L}$ of Actellic (68\%) and $30 \mu \mathrm{L}$ of leaf oil (74\%) had a homogeneous effect on repellency against $B$. chinensis beetles. A homogeneity effect was also found with $40 \mu \mathrm{L}$ of leaf oil (85.33\%) and $40 \mu \mathrm{L}$ of positive control (93.33\%). Statistically, $20 \mu \mathrm{L}$ of leaf oil performed better than $10 \mu \mathrm{L}$ of Actellic $50 \mathrm{EC}$.

\section{DISCUSSION}

Previous research on Dioscorea sansibarensis focused specifically on its medicinal applications; no such research to date has been based on its potential insecticidal, pesticidal or repellency properties. The fumigation studies carried out here showed that among the tested oils, $D$. sansibarensis leaf oils exhibited significant repellent activities. The leaf oil exhibited a repellent activity comparable to that of Actellic $50 \mathrm{EC}$. The results (Table 2) of this study showed that the oil was less effective at lower concentrations; however, larger doses of higher concentrations resulted in enhanced repellent activity. This corroborates the findings of NTONIFOR et al. (2010) that oils at different concentrations exhibited different repellency rates against Coleopterans.

The repellency elicited by the leaf oil may have been due to the presence of $\alpha$-selinene also known as naphthalene, 1,2,3,5,6,7,8,8a-octahydro-1,8a-dimethyl-7-(1-methylethenyl)-,

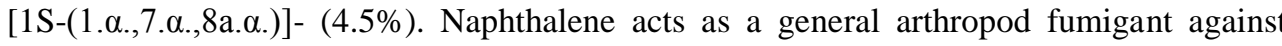
clothes moths and carpet beetles, a microbial inhibitor and an anthelmintic agent. The chemical is also used as a repellent against mammals and birds, i.e. bats, squirrels, rabbits, pigeons, sparrows and starlings (CHEN et al. 1998). Studies of the repellent activity of $\alpha$ selinene, a naphthalene derivative extracted from Muscodor vitigenus DAISY, STROBEL, EZRA \& W.M. HES, exhibited repellency against wheat stem sawfly (Cephus cinctus NORTON, 1872). In an exposure of 7 minutes, 24 out of 30 C. cinctus flies responded by moving to the control arm. The same plugs showed repellent activity to $C$. cinctus flies after 3 weeks where 21 out of 30 flies were repelled by moving to the control arm of the Y-tube olfactometer (DAISY et al. 2002)

\section{CONCLUSION}

These findings indicate the good potential of Dioscorea sansibarensis leaves as a repellent in the management of the bean weevil. Since plant-derived pesticides are 
biodegradable and safer for higher animals, they offer a viable alternative to synthetic agrochemicals (KEDIA et al. 2015). Appropriate effective doses of $D$. sansibarensis leaf oil could save a resource-poor farmer from storage pest losses. Although this study has demonstrated the scientific rationale for the use of $D$. sansibarensis in ethnobotanical legume storage practices, further research on the chemistry and mechanism of action of the bioactive compounds extracted from $D$. sansibarensis is necessary.

\section{ACKNOWLEDGEMENT}

The authors would like to express their gratitude to DAAD-NAPRECA for the study scholarship [Reference number 91560175] for the research topic "Studies on the antifeedant properties of Dioscorea sansibarensis (PAX.) on Bruchus chinensis L. in the protection of stored Phaseolus vulgaris L. beans". We are grateful to Mr. Frank MBAGO of the Botany Departmental Herbarium for identifying the Dioscorea sansibarensis plant material, and to Dr. Fortunatus Sunghwa of the Chemistry Department, University of Dar es Salaam, for facilitating the identification of Dioscorea leaf essential oil constituents, retention index and chemical composition by GC-MS.

\section{REFERENCES}

BurkiLL H.M. 1985. The useful plants of West Tropical Africa. Edition 2. Vol.1. Royal Botanic Gardens, Kew.

Campolo O., Giunti G., Russo A., Palmeri V., Zappalà L. 2018. Essential oils in stored product insect pest control. Journal of Food Quality, 2018: 1-18.

Campos E.V., Proença P.L., Oliveira J.L., Bakshi M., Abhilash P.C., Fraceto L.F. 2018. Use of botanical insecticides for sustainable agriculture: Future perspectives. Ecological Indicators, https://doi.org/10.1016/j.ecolind.2018.04.038

Chen J., Henderson G., Grimm C.C., Lloyd S.W., Laine R.A. 1998. Termites fumigate their nests with naphthalene. Nature, 392 (6676): 558.

Chiluwal K., Kim J., Do BAE S., PARK C.G. 2017. Essential oils from selected wooden species and their major components as repellents and oviposition deterrents of Callosobruchus chinensis (L.). Journal of Asia-Pacific Entomology, 20 (4): 1447-1453.

Daisy B.H., Strobel G.A., Castillo U., Ezra D., Sears J., Weaver D.K., Runyon J.B. 2002. Naphthalene, an insect repellent, is produced by Muscodor vitigenus, a novel endophytic fungus. Microbiology, 148 (11): 3737-3741.

Hong G., Changyan L., Zhenghuang W., Chunyan G. 2017. Growth and development of Bruchus chinensis L. (Coleoptera: Bruchidae) on different beans. Plant Diseases and Pests, 8 (3): 1-3. 
Jayakumar M., Seenivasan S.P., Rehman F., Ignacimuthu S. 2017. Fumigant effect of some essential oils against pulse beetle, Callosobruchus maculatus (FAB.) (Coleoptera: Bruchidae). African Entomology, 25 (1): 193-199.

Karani A.O., Ndakidemi P.A., Mbega E.R. 2017. Botanical pesticides in management of Common bean pests: Importance and possibilities for adoption by small-scale farmers in Africa. Journal of Applied Life Sciences International, 12 (1): 1-10.

Kedia A., Prakash B., Mishra P.K., Singh P., Dubey N.K. 2015. Botanicals as eco-friendly biorational alternatives of synthetic pesticides against Callosobruchus spp. (Coleoptera: Bruchidae) - a review. Journal of Food Science and Technology, 52 (3): 1239-1257.

Kumar S., Das G., Shin H.S., Patra J.K. 2017. Dioscorea spp. (A Wild Edible Tuber): A Study on Its Ethnopharmacological Potential and Traditional Use by the Local People of Similipal Biosphere Reserve, India. Frontiers in Pharmacology, 8: 52.

Kumar S.D., Kumar M.D. 2018. Biology of Pulse Beetle Bruchus chinensis in storage condition in Gram. International Journal of Agriculture Sciences, 10 (7): 5682-5686.

Massalatchi Illyassou K., Adamou R., Schiffers B. 2017. Risk assessment for small farmers exposed to plant protection products in the Niger River valley. Communications in Agricultural and Applied Biological Sciences, 81: 1-13.

MukerJi D., BhuYA M.A. 1937. Reproductive system of the bruchid beetles Bruchus quadrimaculatus FABR., Bruchus (Callosobruchus) chinensis L., (Bruchidae-Coleoptera). Journal of Morphology, 61 (1): 175-221.

Ngowi A.V.F., Mbise T.J., IJAni A.S.M., London L., AJAYi O.C. 2007. Smallholder vegetable farmers in Northern Tanzania: Pesticides use practices, perceptions, cost and health effects. Crop Protection, 26 (11): 1617-1624.

NTONIFoR N.N., OBEn E.O., Konje C.B. 2010. Use of selected plant-derived powders and their combinations to protect stored cowpea grains against damage by Callosobruchus maculatus. Journal of Agricultural and Biological Science, 5 (5): 13-21.

Price E.J., Wilkin P., SARASAn V., Fraser P.D. 2016. Metabolite profiling of Dioscorea (yam) species reveals underutilised biodiversity and renewable sources for high-value compounds. Scientific Reports, 6: 29136.

Sabiha S., Ali H., Hasan K., Rahman A.S.M.S., Islam N. 2017. Bioactive potentials of Melia azedarach $\mathrm{L}$. with special reference to insecticidal, larvicidal and insect repellent activities. Journal of Entomological and Zoological Studies, 5 (5): 1799-1802.

TRIPATHI A.K. 2018. Pests of stored grains. Pests and Their Management. Springer, Singapore.

Trivedi A., NAyak N., Kumar J. 2017. Fumigant toxicity study of different essential oils against stored grain pest Callosobruchus chinensis. Journal of Pharmacognosy and Phytochemistry, 6 (4): $1708-1711$.

UpADHYAY R.K., AhMAD S. 2011. Management strategies for control of stored grain insect pests in farmer stores and public ware houses. World Journal of Agricultural Science, 7 (5): 527-549.

Received: 31 August 2018

Accepted: 27 January 2019 